\title{
DEVELOPMENT OF INTERGOVERNMENTAL FISCAL RELATIONS IN A REGION: THEORY AND PRACTICE ISSUES
}

The paper deals with the issues related to establishment of intergovernmental fiscal relations in Constituent Entities of the Russian Federation. Particular consideration is given to theoretical issues referred to: finance centralization criteria; principles of authority and resource allocation according to territorial levels; efficiency of budget adjustment policy and individual approach to territories.

The author has made close analysis of intergovernmental fiscal relations in municipal entities of the Perm region; as a result, principal issues related to development of the given entities have been set forth. The ways to enhance intra-regional and inter-budget relations in the Russian Federation have been suggested.

Intergovernmental fiscal relations are one of the major factors affecting socio-economic development of a Federal State. Functioning of the State and budget service availability for the population are subject to efficiency and practicality in terms of the way responsibilities and financial resources are allocated between budgets. The issues referred to intergovernmental fiscal relations within the Constituent Entities of the Russian Federation (CE RF) became urgent recently due to the budget system and municipal government reformation. This stipulates elaboration of a theoretical and methodological base in order to establish efficient intergovernmental fiscal relations between regions and municipal entities.

It was mentioned in the budget message by the President of the Russian Federation to the Federal Assembly of the Russian Federation "Regarding the budget policy in 2008-2010" [1, p. 5] that intergovernmental fiscal relations reform is based on withdrawal of "Federal mandates", which are not financially secured; legislative consolidation of power between public authorities of different levels; allocation of proper sources of income to budgets of all levels within the budget system of the Russian Federation on a long-term basis; introduction of transparent and sound adjustment mechanisms of territorial budget supportability; and provision of incentives and improvement of quality of regional and municipal finance management.

Intergovernmental fiscal relations in the Russian Federation have been establishing for over 17 years. The given relations became systemic in 1999, when the Concept of intergovernmental fiscal relations reform was first adopted. According to the given Concept, the subsequent program documents were concerned with improvement of the Budget Code of the Russian Federation and other regulatory documents determining the system of intergovernmental fiscal relations in the Russian Federation. In 2001 the Program of development of budget federalism until 2005 was launched; it was approved by the Government decree № 584 on 15 August 2001.

In 2008 the Concept of efficiency improvement of intergovernmental fiscal relations and public finance management quality for 2006-2008 approved by the Government decree N467-p, 3 April 2006, reached completion. The principal lines in terms of efficiency improvement of intergovernmental fiscal relations and public finance management quality during that period were consolidation of financial autonomy of Constituent Entities of the Russian Federation, provision of incentives to increase income to regional and municipal budgets. 
Apart from the mentioned concepts, not only immediate but also successive transformation of the public sector was of great concern. Primarily, it concerns delineation of responsibilities between authorities of different levels before 2005 . Uppermost, this was reflected in the Federal Acts "Regarding basic principles of organization of legislative (representative) and executive governmental authorities of the Constituent Entities of the Russian Federation" and "Regarding basic principles of organization of a municipal government in the Russian Federation". The given fundamental Acts clearly specify the power by the Constituent Entities and municipal governments. Based on them, income sources for the authority to spend budget funds of the Constituent Entities have been fixed later in the Budget Code of the Russian Federation.

In opinion by many public authorities, by present the tasks specified in the Concept regarding efficiency improvement of intergovernmental fiscal relations and public finance management quality for 2006-2008 have been resolved, and the system of intergovernmental fiscal relations in the Russian Federation is established in general. Basic principles and mechanisms of the system are generated; the role of all participants of the given relations is determined; powers by government bodies are consolidated by relevant normatives [2].

In essence, during 2004-2008 incomes by Constituent Entity budgets showed annual increase of $25 \%$ on an average. However, to what extent was the given increase determined by involvement of Constituent Entity authorities in establishment of an inherent taxation base? The research related to CE RF development in the context of the world financial crisis prove the fact that the budget revenue growth was due not only to new allocation mechanisms, but also, primarily, by the global price growth for basic resources and production in a territory [3, p.184].

The main issues to be solved in order to establish efficient system of intergovernmental fiscal relations in the Russian Federation include the following:

1. Development of balance criteria referred to centralization / decentralization of financial resources within the budgetary federalism system.

Centralization and decentralization properare not an end in itself, they are intended for solving urgent tasks related to government regulation. Such tasks (criteria) might be both political concern regarding enhancement of controllability of territories by the central Government, and setting macroeconomic conditions for their self-development [4]; as well as actualization of the humanistic nature of the budgetary federalism [5] by way of taking social and economic interests of the population into account irrespective of the place of person's residence in the country.

In this connection, centralization and decentralization ratio (according to the amount of allocated functions, resources etc.) may vary subject to system development goals. Therewith, in Russia with its long-term negative experience of extreme centralization an attitude towards decentralization growth is generally positive, towards centralization growth - negative. Nevertheless, suggestions concerned with centralization renewal are occasionally set forth and implemented on certain levels (territorial, branch-wise, functional). Thus, the process of investment resource centralization is observed in a number of budgets of RF Constituent Entities (in the Perm region in particular). Followers of such measures consider centralization to be an indemnity for the funds not to be "squandered", and for the responsible authorities not to be tempted to apply "means of development" for current goals. Nevertheless, such measures violate constitutional rights of municipal governments despite the given arguments being reasonable.

A matter of larger controversy is consolidation of RF Constituent and municipal Entities, which is considered as sharp degradation of territorial decentralization to enhance hypothetic control.

Adequacy, excessiveness or obvious inadequacy of centralization and decentralization are a matter of continual discussions, and, as a rule, such discussions abound in judgmental estimates. This is quite natural, so far as savings or overrun of current administrative costs with centralized or decentralized control are not that hard to estimate, but it is extremely complicated to match these savings or cost overrun with final effect of centralized or decentralized control. We can state with assurance that no proper analysis of final effect of centralization or decentralization was made in the Russian Federation.

2. Substantiation of power and resource allocation principles.

One of the principles of intergovernmental fiscal relations is subsidiarity. It means that powers transfer from lower levels of territorial administration to the center in case if lower level powers cannot be exercised in a proper way. In this case Constituent Entity authorities were to possess only the powers that cannot be exercised efficiently by municipal authorities. In fact, many municipal entities cannot fully resolve the issues "of local significance" assigned to municipal authorities.

What is the reason for that? Municipal potential is subject to fiscal, financial and administrative resources, and the size of the latter depends upon 
tax policy determined by higher authorities proper. In this case unbalance in terms of allocation of competences, powers and resources to exercise them is apparent.

3. Estimation of decentralization efficiency and adjustment policy.

Discussions often involve the fact that decentralization intended for more efficient task solution referred to development of the system's particular parts, enhancement of its functioning etc. makes the system's effective parts even more effective, and weak parts - even weaker, if compared to the centralized control. This actually takes place, but totally different issues lie behind that.

It is beyond controversy that decentralization is capable of fulfilling potential of particular parts of the system (RF Constituent Entities and municipal governments), but provided resource endowment (at least, not below the average than in the system in general) and a control body that is equal to the Center in terms of qualification, energy, material status. Otherwise, centralized control loses its significance and in some cases it is to be abolished (in order to consolidate "decentralization entities", to introduce external control, etc.).

However, fear of intensification (partial renewal) of centralization is so considerable that the center has to fund (centralize, to put it more precisely) part of public resources from all subjects of decentralization and to reallocate the given means. Such adjustment measures are applied everywhere and they almost never resulted in actual increase of resource potential and, ultimately, of the sought-for self-sufficiency and autonomy of weak decentralization subjects. Inefficiency of centralized adjustment policy is a matter of another controversy: does not the given policy reduce general efficiency of system functioning owing to the fact that one of the principal factors of such efficiency - intrasystem competition - is neutralized artificially?

4. Consideration of individual differences in the context of relationship of the center with decentralization subjects equal in terms of the status.

Much controversy concern the fact that a model of equi-status (equi-right) decentralization subjects is often realized at the first level (stage) of decentralization; for instance, the majority of Federal States strive for making Federal Constituent Entities according to the given model. The inevitable result is avowed repeatability of relationships between the center and regions aimed at prevention of infringement of one region for account of the other. To secure such repeatability, it is advisable to use legal norms regarding relationships with the "center", which are principally uniform for all "decentralization subjects"; consistency in terms of basic principles of administration of "decentralization subjects" and the "center" (for instance, consistency of the Constitution of the Russian Federation and Codes, Charters for framework laws of RF Constituent Entities); and appliance of uniform schemes and laws etc. for various relationships (for instance, fiscal, tax).

The given points, being valid in essence, in reality encounter inequality of decentralization subjects in the context of initial state, proper resource potential for exercising uniform powers etc. In other words, the center takes measures within rather differentiated environment in the context of uniform legal, economic and social space, and uniform approaches to such an environment are extremely complicated. A graphic example referred to that is reallocation of budgetary funds accumulated in the center between particular RF Constituent Entities; as a result, only a fifth part can be allocated according to more or less strict rules of "intergovernmental fiscal relations", and the rest is allocated following individual decisions (where judgementally estimated political and other factors are not negligible).

The fact that the given theoretical issues are not resolved, in practice the problems specific of the whole system of intergovernmental fiscal relations exist within a Constituent Entity, and they are even more aggravated and supplemented by specific, "regional", peculiarities, namely: existence of various types of budgetary systems in regions, lack of finances to pursue autonomous intergovernmental fiscal policy, high financial dependence of local budgets on regional ones.

Despite the efforts by regional and municipal governments, the main obstacle for intergovernmental fiscal relations development is growing centralization of financial resources with lack of efficient mechanisms of intergovernmental fiscal relations establishment, which results in increase of a number of subsidized regions and municipalities.

Self-sufficiency of local budgets is provided by proper sources of income and the right to set directions and expenditures. Proper sources of income for budgets are: tax proceeds contributed to budgets according to the Budget Legislation of the Russian Federation and the taxation and revenue legislation; non-tax revenues contributed to budgets according to the legislation of the Russian Federation, the laws by RF Constituent Entities and municipal legal acts by representative bodies of municipal entities; and budget revenues in the form of uncompensated receipts, except for subventions (Section 47, Budget Code RF). 
As a practical matter, non-reciprocal allotment exceeds tax revenue by municipal budgets; low tax and non-tax revenue by local budgets retains (actually, emergence of intergovernmental fiscal relations is concerned with that fact). Only long-term revenue can secure practical self-sufficiency of a budget. Standards of tax revenue allotment by higher authorities are occasionally reviewed (annually, as a rule) by the Federal and regional government authorities, and they may vary arbitrarily both due to rise and reduction of the standard, which does not favor sustainability of interrelation between different budgets.

Relevance to secure long-term standards of municipal budget contributions in line with municipal expenditure authorities was officially stated as far back as 2003. According to the reasonable remark by the Russian President, insufficiency of proper revenue base remains a major issue for municipal governments. However, they have also to bear responsibility to the population for execution of Federal laws (such as the Veteran Act), and for municipal economy functioning, etc. The given problem is still urgent.

As a result, despite municipal budget selfsufficiency was defined legislatively, in reality budgets scarcely possess own resources. The majority of municipal entities are not capable of drawing up local budget solely for the account of own revenues.

Let us consider the issues of intergovernmental fiscal relations by way of example of the Perm region.

Municipal budget supply in the Perm region is equalized by establishment on a regional level of the financial support funds for settlements and municipal districts (city divisions), with the means being allocated between the municipal governments on a formalized basis.

The following funds are drawn up in the budget of the Perm region for 2010 according to the regional budget legislation:

- Regional financial support fund for municipal districts (city divisions) in the scope of 5746.0 million rubles, which is by 278.2 million rubles $(4,6 \%)$ less than in 2009. The Regional financial support fund for municipal districts (city divisions) was drawn up in the scope of $14 \%$ from the design volume of the territorial budget revenue, which complies with regional legislation standards.

The Regional financial support fund for municipal districts (city divisions) for 2011 was drawn up in the scope of 6208.6 million rubles, for 2012 - 6536.7 million rubles;

- The Regional financial support fund for settlements was drawn up in the scope of 287.3 million rubles, which is 13.9 million rubles $(4.6 \%)$ less than in 2009. The Regional financial support fund for settlements is drawn up in the scope of 310.4 million rubles for 2011, in 2012 - 326.8 million rubles.

In the same manner as in 2009 , the Regional financial support fund for the settlements is drawn up in compliance with the regional legislation standards in the scope of $0.7 \%$ from the design volume of the territorial budget revenue. Along with that, no "negative transfers" are used as a source of establishment of the given fund. Settlements being potential payers of "negative transfers" are not subsidized from the Regional financial support fund for settlements.

In compliance with Sector 136 of the Budget Code of the Russian Federation, the Perm City Duma made a decision to renounce the fund assets in 2010, and thus the Regional financial support fund for settlements is allocated between other settlements according to the "per capita" principle;

- The regional compensation fund was drawn up in the scope of 7903.6 million rubles, or by $13 \%$ less than in 2009. For 2011 the regional compensation fund is drawn up in the scope of 8488.2 million rubles, for $2012-8660.5$ million rubles.

The following alterations have been made to the structure of the regional compensation fund:

- subvention for coordination of gambling industry facility disposition and control over disposition and activity by gambling industry facilities (due to termination of the Delegation of power Act from 01.07.2009) is eliminated;

- new subvention for discounting $50 \%$ of education payment for students from economically disadvantaged families at foundations for extended education (due to the Perm region Law revision "On family, maternity, paternity and childhood welfare" entry into force from 01.01.2009 in terms of extra social support) is contemplated;

- means for partial compensation of parents' payment of child support at state and municipal education institutions within the framework of the general program for preschool education (due to revision in 2009 of the Federal standard legal Act concerned with subsiding the mentioned goals from the Federal budget on the co-financing terms) are contemplated;

- expenses for social support of orphans and children deprived of parental care, and expenses for child welfare with regard to minors (transferred to functional classification sector 1000 "Social policy" due to reauthorization between the CE RF and municipal entities);

- emergency fund by the Government of the Perm region in the scope of 200 million rubles. The capacity of the fund is $0.4 \%$ of the budget expenditure and it does not exceed the ceiling value 
defined by Sector 14 of the Perm region Law "On the budgetary process in the Perm region" (3\%). Compared to the original budget for 2009, the emergency fund capacity was not altered. The given fund is contemplated in the scope of 200 million rubles for 2011 and 2012 as well;

- regional fund for cost co-financing in the draft law for 2010-2012, as well as in the approved budget for 2009, was not drawn up.

In general, the revenue potential of municipal entities increased in 2010 in comparison to 2009 (taken into consideration municipal budget curtailment due to the crisis) by $11 \%$.

Financing in terms of "Inter-budget transfers" was reduced more substantially in the Perm region budget costs for 2010 - by 2189.7 million rubles (or by $10.5 \%$ in comparison to 2009 ); its specific weight reduced by $2.3 \%$ within the total costs.

Reduction in expenditure in terms of interbudget transfers is concerned mostly with reduction of the regional fund for financial support due to cut in the revenue part of the budget and in the regional compensation fund.

The author has made a comprehensive analysis of the intergovernmental fiscal relations at the municipal entities of the Perm region. The result is as follows:

- Number of authorities executed by the regional settlements in 2008 and 2009 was less than $50 \%$, contemplated by Sector 14 of the Federal Law № 131-FZ “On general principles of municipal government organization in the Russian Federation";

- According to the estimate by the heads of the settlements, potential to secure all expenditure authorities clothed by the legislation of the Russian Federation on them, is realized (included in the budget and financed) only for $25-30 \%$;

- Reduction of municipal consolidated budget revenues in the Perm region consolidated budget revenues with increasing authority on a local level is observed.

In addition, regulatory and legal framework in terms of intergovernmental fiscal relations of municipal divisions and settlements is not adjusted; when planned budgetary expenditures by settlements are estimated, incomparable coefficients are applied, and it results in obvious unbalance of the settlements' budgets; certain items of the Budget Code of the Russian Federation are violated (lack of Agreements referred to delegation of powers and unauthorized subsidies for equalization of budgets of the settlements); long-term settled standard of establishment of the Regional financial support fund for municipal divisions does not take objective growth of expenses for expenditure authority in the process of budget implementation; etc.

In view of the above said, we consider it essential to take a number of steps at a municipal, regional and federal levels aimed at enhancement of intergovernmental fiscal relations in CE RF, including the Perm region.

Thus, at the level of the CE RF (the Perm region) adjustment of the regional budget legislation with regard to the above-listed unsettled issues is required, as well as augmentation of charges taken from municipal revenues subject to being contributed to the CE budget at a permanent long-term basis.

According to Sector 58 of the Budget Code of the Russian Federation, the law of the CE RF may establish single standards for all municipal divisions of the CE RF referred to the municipal budget contributions form particular federal and (or) regional taxes and dues subject to being contributed to the CE budget according to the Budget Code of the Russian Federation and the taxation and revenue legislation [6]. Therefore, CE RF government bodies are entitled to take an independent decision related to establishment of the mentioned standards. Therewith, regional economic state, level of municipal socio-economic development, extent of the CE budget surplus (deficit), and other factors are taken into consideration.

Along with that, government bodies can also make a decision regarding suspension (reduction) of regional and Federal tax contributions to local budgets. For instance, the Law of the Irkutsk region from 25 November 2008 № 94-oz "On altering the Law of the Irkutsk region "On inter-budgetary transfers and standards of revenue contributions to local budgets" annihilated transport tax contributions to local budgets established earlier; personal income tax standard is reduced from 15 to $10 \%$. Against the subsidy for regional and municipal budget equalization being virtually the same as it was in 2008 in the budget of the Irkutsk region for 2009 [7], suspension and reduction of regional and Federal tax contributions to local budgets have negative effect on consolidation of the economic basis of the local government.

In the Voronezh region, on the contrary, the Law of the Voronezh region from 14 November 2008 № 96-03 “On amendment of the Voronezh region Law "On intergovernmental fiscal relations of the State government bodies and municipal authorities of the Voronezh region" was adopted; it provided for transport tax contribution to municipal budgets in the scope of $100 \%$, according to the standard [8]. According to the Law of the Chelyabinsk region from 30 September 2008 № 
314-30 "On intergovernmental fiscal relations in the Chelyabinsk region" the transport tax standard of municipal budget contribution was set in the scope of $50 \%$ [9]. The above said allows for making a conclusion that when standards of contributions to municipal budgets withdrawn from particular federal and (or) regional taxes and dues subject to being contributed to a CE RF budget in compliance with the Budget Code of the Russian Federation and the Taxation and Revenue Legislation are set, the CE RF legislation introduces collateral guarantees for municipal government financial self-sufficiency.

The above suggestions by the author were fixed in amendment to the Laws of the Perm region "On policy referred to allocation of inter-budget transfers" and "On the budgetary process in the Perm region" in terms of regulation of budget equality and extra sources of their equalization for account of other inter-budget transfers. Since 1 January 2009 taxes subject to being contributed to the regional budget are assigned to the municipal budgets: personal income tax $-15 \%$ (instead of previous 5\%), 100\% of transport tax and $70 \%$ of corporate property tax.

In addition, CEs RF are recommended to include grants to inter-budget transfers to increase quality of municipal finance management and municipal financial development. Steps aimed at relaxation of the economic crisis effects are to be taken: efficient record of changes in the municipal tax base, provision of incentives to local budget revenue growth, involvement of more internal funds to secure municipal activity etc.

It is essential to eliminate the main weak points of the local budget system at a municipal level: extremely low quality of local budgetary process management, which results in high overdue accounts payable; and extremely languid financial planning, where virtually no actual procedures and policies referred to budgetary process management are applied; as a result, municipal government appears incapable of planning (and further execution) of the budget revenue.

Municipal authorities are recommended to take a number of steps in the context of the current situation, for instance: efficient adjustment of revenue forecasts in terms of the current situation, immediate amendment of budgetary decisions for the present year in case of divergence of factual revenues from the forecast rates. Municipal authorities have to analyze validity and efficiency of tax and non-tax revenue exemptions independently and on continuing basis and to amend relevant municipal legal acts.

In conclusion, local budgets are to become truly public instruments: municipal authorities should introduce alternatives of disclosure of budget legal acts and statement to public (it should not be restricted only to their compulsory release in the media), as it will favor public control development. Financial tasks to be solved in the next financial year and ways of their resolution are to be clearly enunciated annually; every municipal entity is to report on task resolution at the end of each financial year.

A calculation methodology referred to legislated expenditure authorities by municipal entities is to be developed at a Federal level. Lack of such a methodology practically results in considerable understatement of subsidies to settlement budgets and failure to execute their authorities.

Relevance of adoption of the given methodology for the Perm region is stipulated by a municipal subsidy level (29 municipal districts and city divisions of the region out of 48 have the subsidy level of over $70 \%)$.

Taking the given steps on an aggregate both in theory and in practice at all the levels can secure enhancement of the intra-regional intergovernmental fiscal relations mechanism and increase its transparency and predictability.

\section{References}

1. The budget message by the President of the Russian Federation to the Federal Assembly of Russian Federation "Regarding the budget policy in 2008-2010". (2007). Pravoved. 10, 3-15.

2. Yurin, A. Enhancement of intergovernmental fiscal relations system at present: web-interview of the Director of the Department of intergovernmental fiscal relations of the Ministry of Finance of the Russian Federation. Retrieved from: http://www.garant.ru/news/223593.

3. Ogloblin, A. (2009). Elaboration of tools for mediumterm prediction of regional development. Regional economics. $4,182-190$

4. Tatarkin A. I., Tatarkin D. A. (2009). Dialectics of establishment and functioning of self-developing territorial economic systems. Federalism. 4, 77-98.

5. Yusubov, E. S. (2009). Methodological background to research of the Russian federalism issues. Constitutional and municipal law. 24, 15-18.

6. Budget Code of the Russian Federation. Russian Federation legislation assembly. 1998. № 31. Item 3823; 2004. № 34. Item 3535; 2007. № 18. Item 2117.

7. On the regional budget for 2008: the Law of the Irkutsk region from 21 May 2008 № 17-oz. Regional. 2008. 28 May; On the regional budget for 2009: the Law of the Irkutsk region from 17 December 2008 № 132-oz. Regional. 2008. 19 December.

8. On amendment of the Voronezh region Law "On intergovernmental fiscal relations of the State government bodies and municipal authorities of the Voronezh region: the Voronezh region Law № 96-03 from 14 November 2008. Young Communard (Molodoy kommunar). 2008. 18 November.

9. On intergovernmental fiscal relations in the Chelyabinsk region: the regional Law № 314-30 from 30 September 2008. South-Ural panorama (Yuzhnouralskaya panorama). 2008, 21 October. 